\section{USPOREDBA KARAKTERISTIKA IGRAČKIH POZICIJA IZMEĐU 12, 15 I 18 STRATEŠKE IGRE KOD JUNIORSKIH AUSTRALIJSKIH FUDBALERA}

\section{COMPARING POSSESSION \\ CHARACTERISTICS \\ BETWEEN 12, 15, AND 18 a \\ SIDE GAMES IN \\ JUNIOR AUSTRALIAN FOOTBALLERS}

\section{Zac Cross ${ }^{1}$, Shane Pill ${ }^{1}$, Kym} Williams ${ }^{1}$

${ }^{1}$ Flinders University College of Education, Psychology and Social Work

Originalni naučni članak doi:10.5550/sgia.181401.se.cpw UDC:796.332-053.6

Primljeno: 01.02.2018. Odobreno: 20.06.2018.

Korespodencija: Dr Shane Pill Flinders University, South Australia GPO Box 2100

Adelaide, South Australia, 5001 shane.pill@flinders.edu.au

Sportlogia 2018, 14 (1), 1-11. E-ISSN 1986-6119 učinke mijenjanja broja igrača tokom 'small sided games' na igračku poziciju kod mladih fudbalera (ispod 10 godina). Dvije modifikovane verzije strateške igre od 12 i 15 igrača koje su u skladu sa pravilima Australijske fudbalske lige (AFL) za

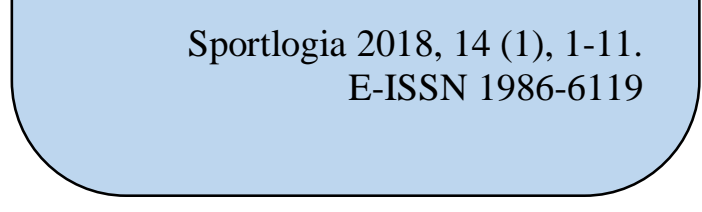
juniore korištene su za upoređivanje sa uobičajenom formacijom od 18 igrača. Igračke pozicije su utvrđene upotrebom IPAD-a uz korištenje aplikacije Dartfish Easy Tag tokom 4 perioda igre od 24 minute za svaki format igre. Utvrđeno je da su dodatni igrači u formaciji od 18 u prosjeku učestvovali u više akcija, međutim, došlo je do smanjenja broja akcija po igraču u usporedbi sa formacijom od 12 i 15 igrača. Također je uočeno da je su se igrači nalazili u boljim pozicijama za udaranje i bacanje po igraču tokom formacija sa 12 i 15 igrača. Rezultati sugerišu da je strateški formacija od 12 igrača prikladnija za djecu uzrasta do 10 godina od formacije sa 18 igrača, jer pruža igračima veću angažovanost, a time i potencijalno veći užitak, angažman i tehnički razvoj igre. Ovo jedinstveno pomaže napredovanju igrača, sticanju vještina i njihovom sudjelovanju u australskom fudbalu.

Ključne riječi: fudbal, strateška igra, juniori, sudjelovanje, angažman igrača

Cross, Z., Pill, Sh., \& Williams, K. (2018). Usporedba karakteristika igračkih pozicija između 12,15 i 18 strateške igre u juniorskom australijskom fudbalu . Sportlogia, 14(1), 1-11. doi:10.5550/sgia.181401.se.cpw Stranica 1. 


\section{INTRODUCTION}

Australian Football (AF) is a high intensity and fast paced invasion game with a unique mixture of various multi-dimensional movement requirements. Despite different positional characteristics, players require elements of speed, agility, aerobic and anaerobic fitness, strength and power to perform the demands of the game (Wisbey, Montgomery, Pyne, \& Rattray, 2010). A match is played between two teams consisting of 18 players on each team, split up into positions with six defenders, six midfielders, six forwards, and four interchange players. The game is played over 20 minute quarters plus 'time on' added for stoppages in play (Gray \& Jenkins, 2010). The primary objective of the game is to kick more total points than the other team. This is achieved by holding onto possession while creating and exploiting space in order to kick goals (6 points) or score 'behinds' or 'points'.

AF provides one of the most popular early engagement in sport programs for children, called the AusKick program (AFL, 2016a), and while its participation numbers continue to grow, this initial interest is not sustained throughout adolescence when compared to other (more popular) invasion sports. This has resulted in a growing concern about retention in AF (Agnew, Pill \& Drummond, 2016). It has been identified that fun and enjoyment are two of the most important aspects of youth participation in sports (Drummond, Agnew, Pill \& Dollman, 2013). Enjoyment is defined as a positive affective response that reflects general feelings such as fun, pleasure and liking (Crane \& Temple, 2015; McCarthy, Jones \& ClarkCarter, 2008), and has been recognised as a strong motivator to participate and a continued desire to stay involved in sport (Agnew, Pill \& Drummond, 2016; Crane \& Temple, 2015; McCarthy, Jones \& Clark-Carter, 2008).

The Sport Commitment Model (Scanlan, Simons, Carpenter, Schmidt \& Keeler, 1993) proposes enjoyment, involvement opportunities, and the attractiveness of other involvement alternatives promote participant retention in team sports. Small sided game (SSG) and scaled versions of AF have been suggested as a means of addressing retention concern, while also improving skill acquisition through greater player engagement (Elliott \& Pill, 2016). However, the junior football association recommends playing with 18 per side, while the Australian Football League Match Day Policy (AFL, 2017) promotes small sided games of 12 and 15 a/side. Nonetheless, the majority of SSGs research has been for drawn from football/soccer, with limited research towards AF (Pill \& Elliot, 2015), despite the AFL Match Policy recommendation of SSG scaled versions of AF at junior levels. Consequently, further research in AF has been recommended to build the case for SSG modified and scaled forms of AF at both practice and for game day competition (Elliott \& Pill, 2016; Phillips \& Wehner, 2012). Therefore, this study aimed to compare game events in 12 a/side and 15 a/side to $18 \mathrm{a}$ /side in under 10s AF. Informed by a previous study in U14 AF by Pill and Elliott (2015), it was hypothesized that 12 and 15 a/side would generate a greater number of game engagement per player compared to traditional approach of $18 \mathrm{a} /$ side.

\section{METHODS}

The research involved a quantitative approach to compare game statistics - kicks, handballs, marks, ground ball pickups and goal attempts, in 12 a side and 15 a side game formats to the 18 a side format used by the junior association in weekend competition. A positivist perspective was adopted as the epistemological stance within this study, as a natural environment (a football club) where observed behaviours (possession characteristics) can be directly measured (Gratton \& Jones, 2010). The study involved the control of possession characteristics to determine the influence that field size and player numbers on player engagement. The project design is similar to that employed by Pill and Elliott (2015).

Cross, Z., Pill, Sh., \& Williams, K. (2018). Usporedba karakteristika igračkih pozicija između 12,15 i 18 strateške igre u juniorskom australijskom fudbalu . Sportlogia, 14(1), 1-11. doi:10.5550/sgia.181401.se.cpw Stranica 2 . 
Quantitative data was collected using real-time tagging using Apple IPad and the application DartFish EasyTag. Dartfish Easy Tag enables a coding panel to be created that helps capture, record and tag live information during a game to derive game-based statistics (Dartfish, 2017). This method of data tagging has been used before by Pill \& Elliot (2015) to record modified junior AF SSGs, with the possession characteristics in this study coded using the Dartfish Easy Tag application. Real-time tagging is also considered by sports teams and sports data companies to be a reliable method to collect sports statistics for sport performance analysis (Bradley, O'Donoghue, Wooster \& Tordoff, 2007; Liu, Hopkins, Gomez \& Molinuevo, 2013; O’Shaughnessy, 2006; Robertson, Gupta \& McIntosh, 2016). An intraoperator reliability test was also completed prior to data collection to help provide the researcher with the necessary practice and understanding of the application before observation commenced. An observation of an Under 18's game between two state league teams was the chosen. The game events, kicks, handballs, marks and goal attempts were tagged for one team across all four quarters of the game. This competition was chosen as the games are tagged by Champion Data and the tagging tallies are publically available from the league. The difference between the intra-operator test results and those of Champion Data was found to be insignificant.

The recruitment of the football club was by convenience sampling (Patton, 2015). The club was then contacted via their publicly available details on their club website. The project was discussed with club, with the club agreed to be a part of the research.

The data collection was not individually identifiable from player to player and was solely focused on the game events (kicks, marks, handballs, ground ball pickups, goal attempts). The five possession characteristics were chosen as they are common in AF game tagging analysis (i.e., Champion Data). The possession characteristics definition is provided in Table 1.

Table 1. Australian Football possession characteristics definitions (AFL, 2016b)

Kick: An act of disposing of the football, when a player contacts the football with any part of the player's leg below the knee.

Handball: A player holds the football in one hand and disposes of the football by hitting it with the clenched fist of the other hand.

Mark: A mark to the body is taken if a player catches or takes control of the football within the playing surface, after it has been kicked by another player, and which has not touched the ground or been touched by another player during the period when the football was kicked until it was caught or controlled by the player to the body.

Ground ball pickup: A player taking possession of the ball while in dispute, off the ground.

Goal attempts: Recording of either 1 or 6 points, under any of the following conditions: (1) when the football is kicked completely over the goal line by a player of the attacking team without being touched by any other player, even if the ball first touches the ground; (2) the football passes completely over the behind line; (3) a player of the attacking team kicks the football over the goal line but before passing over the goal line, the ball is touched by another player; or (4) the football passes touches or passes over the goal post or touches the padding or any other attachment to the goal post

The playing area was consistent with the AFL match policy of $140 \mathrm{~m} \times 80 \mathrm{~m}$; the surface area per player was $698 \mathrm{~m} 2$ in the $18 \mathrm{a}$ /side format compared to $1,047 \mathrm{~m} 2$ during the $12 \mathrm{a} /$ side games. The AFL Match Policy thus provides greater space per player in the $12 \mathrm{a}$ side format.

Cross, Z., Pill, Sh., \& Williams, K. (2018). Usporedba karakteristika igračkih pozicija između 12,15 i 18 strateške igre u juniorskom australijskom fudbalu . Sportlogia, 14(1), 1-11. doi:10.5550/sgia.181401.se.cpw Stranica 3. 
Data was compared between the four game periods of 24 minutes for each game format, with descriptive statistics (mean, standard deviation and frequency counts) calculated holistically per game period (Table 4 and 5), and per player (Table 6 and 7). Cohen's d magnitude-based inferences were employed to further understand the level of statistical importance between selected possession and match characteristics between the three game formats $(<0.2$ trivial, $0.2-0.5$ small, $0.5-0.8$ moderate, $0.8>$ Large (Cohen, 1988). Effects with $95 \%$ confidence limits (CL) overlapping the thresholds for small positive and negative effects (exceeding 0.2 standard deviations either side of the null hypothesis) were defined as unclear, with clear small, moderate and large effect sizes defined as substantial.

\section{RESULTS}

The analysis of total possession and match characteristics showed that there was a small increase in kicks achieved for the 12 a/side $(d=0.39$, CL $-0.36-1.11), 15 /$ side $(d=$ 0.33 , CL -0.37 - 1.01) compared to the $18 \mathrm{a}$ /side. In addition, there was a small increase between marks achieved for the 12 a side $(d=0.34, \mathrm{CL}-0.41-1.07)$ compared to the 18 a/side. Conversely, 12 and 15 a/side demonstrated a small to large decrease for handballs, groundball pick-ups, goal attempts and total tagged events compared to the18 a side game format. In a secondary comparison, 12 a/side demonstrated a small increase in handballs $(d=$ $0.42, \mathrm{CL}-0.36-1.18)$ and goal attempts $(d=0.34$, CL - $0.43-1.10)$ achieved compared to $15 \mathrm{a}$ /side game format, while differences in marks, groundball pick-ups and total tagged events were trivial.

Table 2. Summary of tagged events for 12,15 and 18 a/side games

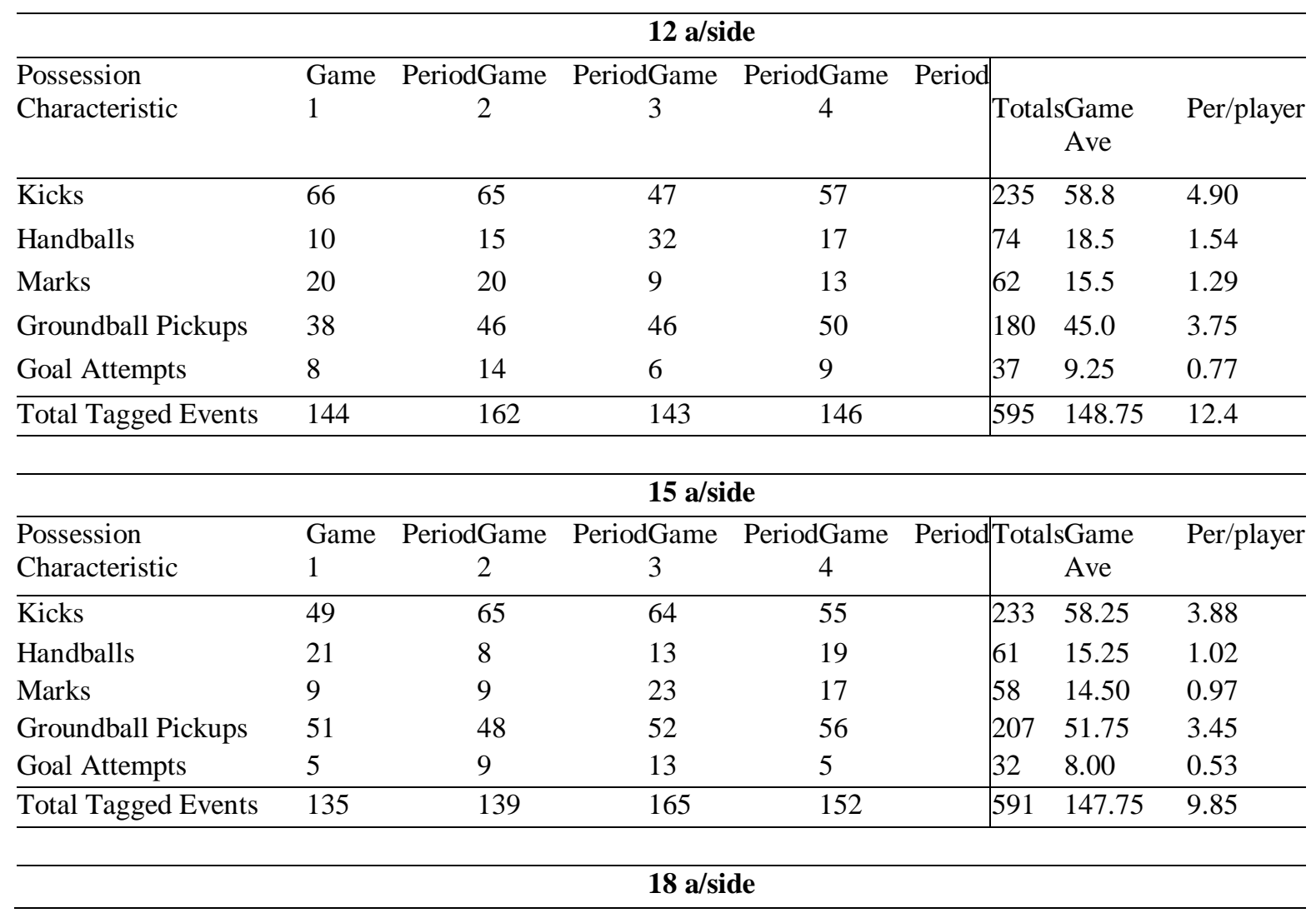

Cross, Z., Pill, Sh., \& Williams, K. (2018). Usporedba karakteristika igračkih pozicija između 12,15 i 18 strateške igre u juniorskom australijskom fudbalu. Sportlogia, 14(1), 1-11. doi:10.5550/sgia.181401.se.cpw Stranica 4. 


\begin{tabular}{llcccclcc}
\hline Possession & Game & PeriodGame & PeriodGame & PeriodGame & Period TotalsGame & Per/player \\
Characteristic & 1 & 2 & 3 & 4 & & Ave & \\
\hline Kicks & 63 & 54 & 55 & 53 & 225 & 56.25 & 3.13 \\
Handballs & 20 & 18 & 25 & 13 & 76 & 19.00 & 1.06 \\
Marks & 14 & 15 & 13 & 13 & & 55 & 13.75 & 0.76 \\
Groundball Pickups & 56 & 53 & 55 & 46 & & 213 & 52.50 & 2.92 \\
Goal Attempts & 15 & 15 & 10 & 6 & 46 & 11.50 & 0.64 \\
\hline Total Tagged Events & 170 & 157 & 162 & 130 & 619 & 154.75 & 8.60 \\
\hline
\end{tabular}

Table 3. Analysis of total possession and match characteristics during the games

\begin{tabular}{|c|c|c|c|c|c|c|}
\hline & $12 /$ side & $\begin{array}{c}12 \rightarrow 15 \\
\text { ES (LB } \\
\text { and UB) }\end{array}$ & 15/side & $\begin{array}{c}12 \rightarrow 18 \\
\text { ES (LB } \\
\text { and UB) }\end{array}$ & 18/side & $\begin{array}{c}15 \rightarrow 18 \\
\text { ES (LB } \\
\text { and UB) } \\
\end{array}$ \\
\hline Kicks & $\begin{array}{c}58.8 \pm \\
8.1\end{array}$ & $\begin{array}{c}0.07 \\
(-0.69- \\
0.82)\end{array}$ & $\begin{array}{c}58.3 \pm \\
7.6\end{array}$ & $\begin{array}{c}0.39 \\
(-0.36- \\
1.11)\end{array}$ & $56.25 \pm 4.6$ & $\begin{array}{c}0.33 \\
(-0.37- \\
1.01)\end{array}$ \\
\hline Handballs & $\begin{array}{c}18.5 \pm \\
9.5\end{array}$ & $\begin{array}{c}0.42 \\
(-0.36- \\
1.18)\end{array}$ & $\begin{array}{c}15.3 \pm \\
5.9\end{array}$ & $\begin{array}{c}-0.07 \\
(-0.80- \\
0.66)\end{array}$ & $19 \pm 5.0$ & $\begin{array}{c}-0.69 \\
(-1.38- \\
0.03)\end{array}$ \\
\hline Marks & $\begin{array}{c}15.5 \pm \\
5.4\end{array}$ & $\begin{array}{c}0.15 \\
(-0.62- \\
0.90)\end{array}$ & $\begin{array}{c}14.5 \pm \\
7.6\end{array}$ & $\begin{array}{c}0.34 \\
(-0.41- \\
1.07)\end{array}$ & $13.75 \pm 5.0$ & $\begin{array}{c}0.12 \\
(-0.57- \\
0.80)\end{array}$ \\
\hline $\begin{array}{l}\text { Groundball } \\
\text { pick-ups }\end{array}$ & $\begin{array}{c}45.0 \pm \\
5.4\end{array}$ & $\begin{array}{c}-1.18 \\
(-1.96-- \\
0.33)\end{array}$ & $\begin{array}{c}51.8 \pm \\
5.9\end{array}$ & $\begin{array}{c}-1.53 \\
(-2.31-- \\
0.67)\end{array}$ & $52.5 \pm 4.5$ & $\begin{array}{c}-0.14 \\
(-0.83- \\
0.55)\end{array}$ \\
\hline Goal attempts & $9.3 \pm 3.4$ & $\begin{array}{c}0.34 \\
(-0.43- \\
1.10)\end{array}$ & $8.0 \pm 3.8$ & $\begin{array}{c}-0.56 \\
(-1.29- \\
0.20)\end{array}$ & $11.5 \pm 4.4$ & $\begin{array}{c}-0.85 \\
(-1.54-- \\
0.11)\end{array}$ \\
\hline Total tagged events & $\begin{array}{l}149.0 \pm \\
8.92\end{array}$ & $\begin{array}{c}0.08 \\
(-0.68- \\
0.84)\end{array}$ & $\begin{array}{c}147.8 \pm \\
13.6\end{array}$ & $\begin{array}{c}-0.41 \\
(-1.14- \\
0.34)\end{array}$ & $\begin{array}{c}154.75 \\
\pm \\
17.3\end{array}$ & $\begin{array}{c}-0.44 \\
(-1.13- \\
0.26)\end{array}$ \\
\hline
\end{tabular}

In secondary analysis, there was a considerable large increase in kicks achieved for the $12 /$ a side $(d=3.53$, CL $2.30-4.57), 15 /$ side $(d=1.92$, CL $1.06-2.70)$, compared to the 18 a/side, and between 12 a/side $(d=1.65$, CL $0.73-2.47)$ and 15 a side game formats. In addition, $12 \mathrm{a}$ /side displayed a large increase in handballs achieved compared to both $15 \mathrm{a}$ side $(d=0.95$, CL $0.15-1.69)$ and 18 a/side $(d=0.95$, CL $0.15-1.69)$. A similar large increase was also observed between goal attempts in the 12 a side ( $d=0.90$, CL $0.08-1.66)$ compared to 15 a/ side. Finally, a large increase in total tagged events was also observed for $12 \mathrm{a} /$ side $(d=4.46$, CL $3.02-5.65)$ and $15 /$ side $(d=1.33$, CL $0.55-2.05)$, compared to 18 a side game format.

Cross, Z., Pill, Sh., \& Williams, K. (2018). Usporedba karakteristika igračkih pozicija između 12,15 i 18 strateške igre u juniorskom australijskom fudbalu . Sportlogia, 14(1), 1-11. doi:10.5550/sgia.181401.se.cpw Stranica 5. 
Table 4. Summary of tagged events

\begin{tabular}{|c|c|c|c|c|c|c|}
\hline \multicolumn{7}{|c|}{12 a/side } \\
\hline $\begin{array}{c}\text { Possession } \\
\text { Characteristic } \\
\end{array}$ & $\begin{array}{c}\text { Game } \\
\text { Period } 1\end{array}$ & $\begin{array}{c}\text { Game } \\
\text { Period } 2\end{array}$ & $\begin{array}{c}\text { Game } \\
\text { Period } 3 \\
\end{array}$ & $\begin{array}{c}\text { Game } \\
\text { Period } 4 \\
\end{array}$ & Totals & $\begin{array}{c}\text { Ave } \\
\text { per/player }\end{array}$ \\
\hline Kicks & 5.50 & 5.42 & 3.92 & 4.75 & 19.58 & 4.9 \\
\hline Handballs & 0.83 & 1.25 & 2.67 & 1.42 & 6.17 & 1.54 \\
\hline Marks & 1.67 & 1.67 & 0.75 & 1.08 & 5.17 & 1.29 \\
\hline Groundball Pickups & 3.17 & 3.83 & 3.83 & 4.17 & 15.00 & 3.75 \\
\hline Goal Attempts & 0.67 & 1.17 & 0.50 & 0.75 & 3.08 & 0.77 \\
\hline Total Tagged Events & 12.00 & 13.50 & 11.92 & $\begin{array}{c}12.1 \\
7\end{array}$ & 49.58 & 12.4 \\
\hline
\end{tabular}

\begin{tabular}{|c|c|c|c|c|c|c|}
\hline & & & & & & \\
\hline $\begin{array}{l}\text { Possession } \\
\text { Characteristic }\end{array}$ & $\begin{array}{l}\text { Game } \\
\text { Period } 1\end{array}$ & $\begin{array}{l}\text { Game } \\
\text { Period } 2\end{array}$ & $\begin{array}{l}\text { Game } \\
\text { Period } 3\end{array}$ & $\begin{array}{l}\text { Game } \\
\text { Period } 4\end{array}$ & Totals & $\begin{array}{c}\text { Ave } \\
\text { per/player }\end{array}$ \\
\hline Kicks & 3.27 & 4.33 & 4.27 & 3.67 & 15.53 & 3.88 \\
\hline Handballs & 1.40 & 0.53 & 0.87 & 1.27 & 4.07 & 1.02 \\
\hline Marks & 0.60 & 0.60 & 1.53 & 1.13 & 3.87 & 0.97 \\
\hline Groundball Pickups & 3.40 & 3.20 & 3.47 & 3.73 & 13.80 & 3.45 \\
\hline Goal Attempts & 0.33 & 0.60 & 0.87 & 0.33 & 2.13 & 0.53 \\
\hline Total Tagged Events & 9.00 & 9.27 & 11.00 & $\begin{array}{c}10.1 \\
3\end{array}$ & 39.40 & 9.85 \\
\hline
\end{tabular}

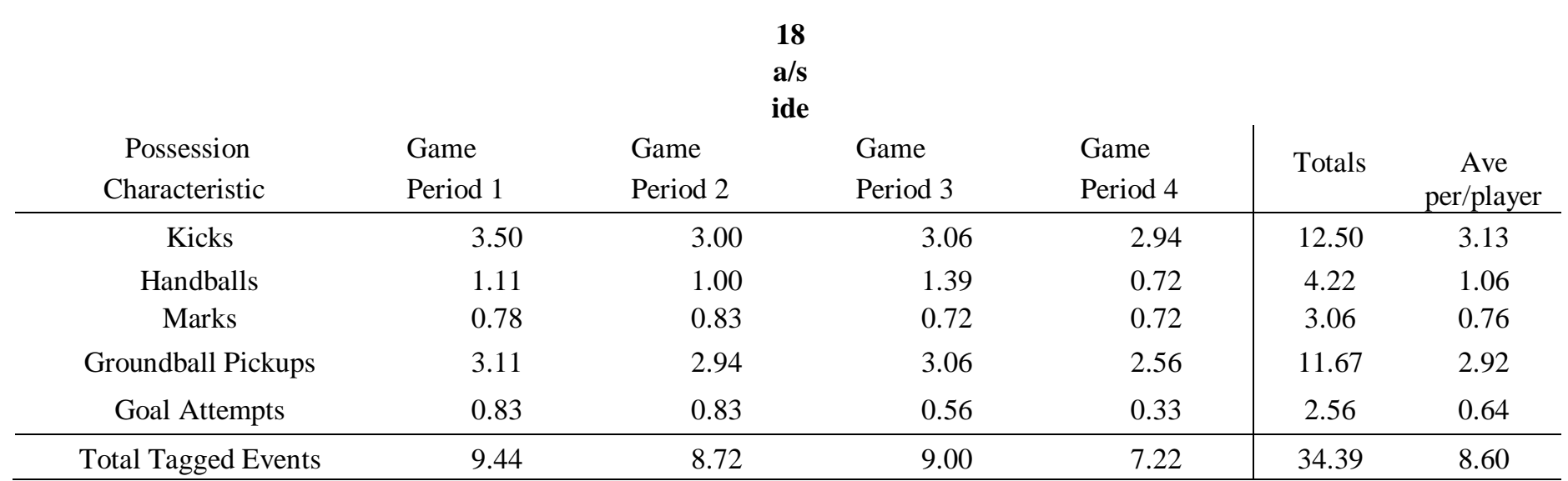

Cross, Z., Pill, Sh., \& Williams, K. (2018). Usporedba karakteristika igračkih pozicija između 12,15 i 18 strateške igre u juniorskom australijskom fudbalu . Sportlogia, 14(1), 1-11. doi:10.5550/sgia.181401.se.cpw Stranica 6. 
Table 5. Possession and match characteristics per player during the 12, 15, and 18 a/side games. Descriptive statistics are displayed as mean $(\tilde{x})$ and standard deviations (SD). ES refers to Cohen's $d$ effect size, with the LB and UB referring to the lower and upper bound $95 \%$ confidence limits.

\begin{tabular}{|c|c|c|c|c|c|c|}
\hline & 12/side & $\begin{array}{c}12 \rightarrow 15 \\
\text { ES (LB and } \\
\text { UB) }\end{array}$ & 15/side & $\begin{array}{c}12 \rightarrow 18 \\
\text { ES (LB and } \\
\text { UB) }\end{array}$ & 18/side & $\begin{array}{c}15 \rightarrow 18 \\
\text { ES (LB and } \\
\text { UB) }\end{array}$ \\
\hline Kicks & $\begin{array}{c}4.90 \pm \\
0.73\end{array}$ & $\begin{array}{c}1.65 \\
(0.73-2.47)\end{array}$ & $\begin{array}{c}3.88 \pm \\
0.51\end{array}$ & $\begin{array}{c}3.53 \\
(2.30- \\
4.57)\end{array}$ & $\begin{array}{r}3.13 \pm \\
0.25\end{array}$ & $\begin{array}{c}1.92 \\
(1.06-2.70)\end{array}$ \\
\hline Handballs & $\begin{array}{c}1.54 \pm \\
0.73\end{array}$ & $\begin{array}{c}0.91 \\
(0.09-1.68)\end{array}$ & $\begin{array}{c}1.02 \pm \\
0.39\end{array}$ & $\begin{array}{c}0.95 \\
(0.15- \\
1.69)\end{array}$ & $\begin{array}{r}1.06 \pm \\
0.28\end{array}$ & $\begin{array}{c}-0.13 \\
(-0.81- \\
0.56)\end{array}$ \\
\hline Marks & $\begin{array}{c}1.29 \pm \\
0.45\end{array}$ & $\begin{array}{c}0.71 \\
(-0.10- \\
1.47)\end{array}$ & $\begin{array}{c}0.97 \pm \\
0.45\end{array}$ & $\begin{array}{c}1.85 \\
(0.94- \\
2.66)\end{array}$ & $\begin{array}{r}0.76 \pm \\
0.05\end{array}$ & $\begin{array}{c}0.67 \\
(-0.05- \\
1.36)\end{array}$ \\
\hline $\begin{array}{l}\text { Groundball pick- } \\
\text { ups }\end{array}$ & $\begin{array}{c}3.75 \pm \\
0.42\end{array}$ & $\begin{array}{c}0.93 \\
(0.10-1.70)\end{array}$ & $\begin{array}{c}3.45 \pm \\
0.22\end{array}$ & $\begin{array}{c}2.54 \\
(1.51- \\
3.43)\end{array}$ & $\begin{array}{r}2.92 \pm \\
0.25\end{array}$ & $\begin{array}{c}2.24 \\
(1.32-3.05)\end{array}$ \\
\hline Goal attempts & $\begin{array}{c}0.77 \pm \\
0.28\end{array}$ & $\begin{array}{c}0.90 \\
(0.08-1.66)\end{array}$ & $\begin{array}{c}0.53 \pm \\
0.26\end{array}$ & $\begin{array}{c}0.17 \\
(-0.57- \\
0.90)\end{array}$ & $\begin{array}{r}0.64 \pm \\
0.96\end{array}$ & $\begin{array}{c}-0.15 \\
(-0.83- \\
0.54)\end{array}$ \\
\hline Total tagged events & $\begin{array}{c}12.4 \pm \\
0.64\end{array}$ & $\begin{array}{c}3.18 \\
(1.96-4.20)\end{array}$ & $\begin{array}{c}9.85 \pm \\
0.91\end{array}$ & $\begin{array}{c}4.46 \\
(3.02- \\
5.65)\end{array}$ & $\begin{array}{r}8.6 \pm \\
0.96\end{array}$ & $\begin{array}{c}1.33 \\
(0.55-2.05)\end{array}$ \\
\hline
\end{tabular}

\section{DISCUSSION}

It was hypothesised that 12 and $15 \mathrm{a}$ /side would generate a greater number of game engagement per player compared to traditional approach of $18 \mathrm{a} / \mathrm{side}$. This hypothesis has been found to be correct. The findings in this study suggest that by competitively engineering (Burton, Gillham \& Hammermeister, 2011; Elliot \& Pill, 2016) AF for Under 10's, characterized by altering the number of players on the field, specific player development aspects can be significantly improved or constrained. Consistent with previous studies (Katis \& Kellis, 2009; Owen, Twist \& Ford, 2004; Pill \& Elliot, 2015; Small, 2006), the total number of tagged possession characteristics per player was greater in the $12 \mathrm{a} /$ side games compared to the $15 \mathrm{a}$ /side and $18 \mathrm{a} /$ side games. There was a $30.6 \%$ increase of possession characteristics per player during the 12 a side SSGs with 12.4 per person per 24 minutes compared to the 8.60 per person per 24 minutes achieved during the 18 a/side game. This indicates that SSGs (where playing numbers are reduced) increases the number of participation per player, therefore allowing players to perform skills at a greater rate, which in turn accelerates their skill development compared to traditional 18 a/side format.

Kicking and handballing were found to have no significant difference between the total number of kicks and handballs within the 12, 15 and 18 a/side games. However, consistent with previous findings from Pill and Elliot (2015), the average number of possessions per player shows that $12 \mathrm{a}$ /side AF elicits significantly more kicks (4.9 per player) and handballs (1.54 per player) than the 15 and $18 \mathrm{a} /$ side format. This result

Cross, Z., Pill, Sh., \& Williams, K. (2018). Usporedba karakteristika igračkih pozicija između 12,15 i 18 strateške igre u juniorskom australijskom fudbalu . Sportlogia, 14(1), 1-11. doi:10.5550/sgia.181401.se.cpw Stranica 7. 
demonstrate that players are provided with more opportunities in the SSGs versions to obtain and distribute the ball, therefore allowing an increased level of engagement per player.

The results from this study also suggest that by decreasing the number of players on the field, the amount of marks per player may be more frequent. Players recorded $41 \%$ more marks per player in the $12 \mathrm{a}$ /side modification compared to the $18 \mathrm{a} / \mathrm{side}$ games. This may be because the $12 \mathrm{a}$ /side game constraints of keeping the playing area constant and reducing playing numbers resulted in increasing the playing space per person compared to the 18 a side format. Players have a larger proximity to each other in $12 \mathrm{a} /$ side games which may result in more uncontested marking attempts and therefore greater opportunity to develop marking ability.

The finding also demonstrated that there was a decrease in the number of groundball pick-ups during 12 a side version compared to the larger numbered 15 and 18 a/side games. The efficiency of possessions, the amount of kicks kicked towards a contested situation and the increased congestion in the 18 a side games had a direct impact towards the higher number of groundball pick-ups in this game format. Pill and Elliot (2015) observed a similar finding and suggested that the high amount of groundball pick-ups was somewhat due to the player's inability to kick at the correct trajectory so that the ball would make the distance and accuracy to the intended target to be able to mark the ball when playing on the larger fields. Participants in the Pill and Elliott (2015) study were under 14's. At U10 level, the age level of participants in this study, this (in) ability to get a kick to the intended player when playing in the larger space, and thus with potentially greater distance between players, can reasonably be suggested and account for the differential in ground ball pick-ups between the game versions.

An unexpected finding of this study was the decrease in goal attempts during the smaller scaled 12 and $15 \mathrm{a} /$ side games compared to the $18 \mathrm{a} /$ side game. In contrast to previous studies involving AF and soccer (Katis \& Kellis, 2009; Owen, Twist \& Ford, 2004; Pill \& Elliot, 2015; Small, 2006) that suggested decreasing the numbers in SSGs increased the amount of scoring attempts and goals, this study had the opposite finding. In this study, reducing the number of players resulted in the amount of goal attempts decreasing.

\section{CONCLUSION}

The AFL Match Policy emphasises that at U10s level and below, AF training and matches should focus on 'fundamental' game skills such as kicking, handballing, marking and gathering the ball. The findings in this study suggests that competitively engineering the game form in $\mathrm{AF}$ for reduced player numbers and smaller fields may enhance player development as each player has the potential for greater game engagement than in game forms with more players and on larger fields. Further research is still required to further develop our understanding of how SSGs can affect player development and participation in AF, specifically junior AF. Determining what task and player constraint for game formats that elicits the optimal number technical demands and ball contacts for player development and engagement and how SSGs can be used as an education tool is two important areas that should be further investigated. To date, there is only one previous study (Pill \& Elliot, 2015) that investigated the effects of player constraints (number of players) and environment constraints (dimensions of the playing area) on player possession characteristics in junior AF.

As fun, enjoyment and perceived competence are key factors in youth retention in sports, it is recommended for future research to investigate the levels of enjoyment and perceived competence in children participating in AF SSG formats in training and match day. This will allow for further understanding of the benefit of scaled game forms in junior AF competitions and allows for player experiences to be a focus when competition engineering is

Cross, Z., Pill, Sh., \& Williams, K. (2018). Usporedba karakteristika igračkih pozicija između 12,15 i 18 strateške igre u juniorskom australijskom fudbalu . Sportlogia, 14(1), 1-11. doi:10.5550/sgia.181401.se.cpw Stranica 8. 
being investigated. We recommend that longitudinal case study that tracks possession characteristics, players' development, participation and experiences of competition engineering for a whole season is required to further advance the field of knowledge.

\section{REFERENCES}

Agnew, D., Pill, S., \& Drummond, M. (2016). Investigating the elements that encourage or inhibit the participation of children and youth in Australian Football. Annals of Leisure Research, 19(1), 27-46.

https://doi.org/10.1080/11745398.2015.1036898

Australian Football League. (2016a). 2016 Annual Report. Retrieved from http://www.afl.com.au/afl-hq/annual-reports

Australian Football League. (2016b). The coach: The official AFL level 1 coaching manual. Retrieved from http://www.aflcommunityclub.com.au/index.php?id=370

Australian Football League. (2017). Australian Football Match Policy. Retrieved from http://www.aflcommunityclub.com.au/index.php?id=32

Bradley, P., O'Donoghue, P., Wooster, B., \& Tordoff, P. (2007). The reliability of ProZone MatchViewer: a video-based technical performance analysis system. International Journal of Performance Analysis in Sport, 7(3), 117-129.

https://doi.org/10.1080/24748668.2007.11868415

Burton, D., Gillham, A., \& Hammermeister, J. (2011). Competitive engineering: Structural climate modifications to enhance youth athletes' competitive experience. International Journal of Sports Science and Coaching, 6(2), 201-217. https://doi.org/10.1260/17479541.6.2.201

Cohen, J. (1988). Statistical power analysis for the behavioral sciences. Hilsdale. NJ: Lawrence Earlbaum Associates. https://doi.org/10.1002/bs.3830330104

Crane, J., \& Temple, V. (2015). A systematic review of dropout from organized sport among children and youth. European physical education review, 21(1), 114-131. https://doi.org/10.1177/1356336X14555294

Dartfish. (2017). Dartfish EasyTag. Retrieved from www.dartfish.com/easytag

Drummond, M., Agnew, D., Pill, S., \& Dollman, J. (2013). SANFL youth retention project. Adelaide, AUS. Flinders University.

Elliott, S., \& Pill, S. (2016). Competitive engineering in junior Australian football: perceptions and experiences of parents, children and coaches of 9-a-side football in an Under-8 competition. South African Journal for Research in Sport, Physical Education and Recreation, 38(1), 43-57.

Gratton, C., \& Jones, I. (2010). Research methods for sports studies. London, GBR: Taylor \& Francis.

Gray, A. J., \& Jenkins, D.G. (2010). Match analysis and the physiological demands of Australian Football. Sports Medicine, 40(4), 347-360. https://doi.org/10.2165/11531400-000000000-00000 PMid:20364877

Katis, A., \& Kellis, E. (2009). Effects of small-sided games on physical conditioning and performance in young soccer players. Journal of Sports Science and Medicine, 8, 374380.

https://www.jssm.org/hf.php?id=jssm-08-374.xml\#

Liu, H., Hopkins, W., Gómez, A. M., \& Molinuevo, S. J. (2013). Inter-operator reliability of live football match statistics from OPTA Sportsdata. International Journal of

Cross, Z., Pill, Sh., \& Williams, K. (2018). Usporedba karakteristika igračkih pozicija između 12,15 i 18 strateške igre u juniorskom australijskom fudbalu. Sportlogia, 14(1), 1-11. doi:10.5550/sgia.181401.se.cpw Stranica 9. 
Performance Analysis in $\quad$ Sport, $\quad$ 13(3), $\quad$ 803-821. https://doi.org/10.1080/24748668.2013.11868690

McCarthy, P. J., Jones, M. V., \& Clark-Carter, D. (2008). Understanding enjoyment in youth sport: A developmental perspective. Psychology of sport and exercise, 9(2), 142156. https://doi.org/10.1016/j.psychsport.2007.01.005

O’Shaughnessy, D. M. (2006). Possession versus position: strategic evaluation in AFL. Journal of sports science \& medicine, 5(4), 533-540. https://www.jssm.org/hf.php?id=jssm-05-533.xml

Owen, A., Twist, C., \& Ford, P. (2004). Small-sided games: the physiological and technical effect of altering pitch size and player numbers. Insight, 7(2), 50-53.

Patton, M. (2015). Qualitative research and evaluation methods (4th ed.). Los Angeles, USA. Ca: Sage.

Phillips, P., \& Wehner, K. (2012). Examining the AFL junior match policy for recruitment and retention report. Australia. Deakin University.

Pill, S., \& Elliott, S. (2015). Effects of altering the number of players and the dimensions of the playing area on the possession characteristics in youth Australian Football. Sport Science Review, 24(3-4), 171-192.

https://doi.org/10.1515/ssr-2015-0014

Robertson, S., Gupta, R., \& McIntosh, S. (2016). A method to assess the influence of individual player performance distribution on match outcome in team sports. Journal of Sports Sciences, 34(19), 1893-1900. https://doi.org/10.1080/02640414.2016.1142106 PMid:26853070

Scanlan, T. K., Simons, J. P., Carpenter, P. J., Schmidt, G. W., \& Keeler, B. (1993). An introducion to the sport commitment model. Journal of Sport \& Exercise Psychology, 15(1), 1-15. https://doi.org/10.1123/jsep.15.1.1

Small, G. (2006). Small-sided games study of young football players in Scotland. Independent Consultation Paper; Dundee, UK. University of Abertay.

Wisbey, B., Montgomery, P. G., Pyne, D. B., \& Rattray, B. (2010). Quantifying movement demands of AFL football using GPS tracking. Journal of Science and Medicine in Sport, 13(5), 531-536.

https://doi.org/10.1016/j.jsams.2009.09.002

PMid: 19897414

Cross, Z., Pill, Sh., \& Williams, K. (2018). Usporedba karakteristika igračkih pozicija između 12,15 i 18 strateške igre u juniorskom australijskom fudbalu . Sportlogia, 14(1), 1-11. doi:10.5550/sgia.181401.se.cpw Stranica 10. 


\begin{abstract}
The purpose of this investigation was to compare the effects of altering the number of players during 'small sided games' on the possession characteristics within a youth under10 football setting. Two modified 'small sided game' versions of 12 a side and 15 a side in accordance to the Australian Football League (AFL) junior match policy were used to compare against the 18 a side game used in a junior football association. Possession characteristics were coded using IPad installed with the application Dartfish Easy Tag across 4 game periods of 24 minutes for each game format. It was found that the additional players in the 18 a side version led to more tagged events on average, however, there was a decrease in the number of tagged actions per player compared to 12 a/side and 15 a/side. It was also observed that there were more possession characteristics for kicking and handballing per player during the 12 a/side and 15 a/side versions. The findings suggested that the 12 a side game version of Australian Football is more appropriate for under 10 than the 18 a side format, as it provides players with greater involvement and therefore potentially greater enjoyment, engagement, and technical game-based development. This uniquely aids player development, skill acquisition and participation levels in junior Australian footballers.
\end{abstract}

Key words: football, small sided, juniors, participation, player engagement.

Primljeno: 01.02.2018.

Odobreno: 20.06.2018.

Korespodencija:

Dr Shane Pill

Flinders University, South Australia

GPO Box 2100

Adelaide, South Australia, 5001

shane.pill@flinders.edu.au

Cross, Z., Pill, Sh., \& Williams, K. (2018). Usporedba karakteristika igračkih pozicija između 12,15 i 18 strateške igre u juniorskom australijskom fudbalu . Sportlogia, 14(1), 1-11. doi:10.5550/sgia.181401.se.cpw Stranica 11. 